Mafor Penn

Faculty of Education, University of Johannesburg

E-mail: mpenn@uj.ac.za

Umesh Ramnarain

Professor, Science Education

Faculty of Education University of Johannesburg E-mail:

uramnarain@uj.ac.za

DOI: $h$ ttp://dx.doi.

org/10.18820/2519593X/pie.

v37i2. 6

ISSN 0258-2236

e-ISSN 2519-593X

Perspectives in Education

2019 37(2): 80-97

Date Published:

27 November 2019

\section{A comparative analysis of virtual and traditional laboratory chemistry learning}

\begin{abstract}
Laboratory experimentation in the context of school science is a widely advocated teaching strategy for the simplification of several abstract scientific concepts. Laboratory-based learning activities have proven to enhance learners' conceptual and procedural understandings of micro chemical phenomena, thus boosting achievement in chemistry content tests. In the South African education landscape where there is inequitable distribution of resources for laboratory-based science learning, this study exploited how available virtual learning resources could also be used for learning chemistry concepts, and further compared student achievement in chemistry content test post intervention with both traditional and virtual laboratory learning resources. In this quasi- experimental study, we provided a group of third-year pre-service science teachers $(n=50)$ with four chemistry concepts to learn using a hands-on traditional (control group) and a virtual laboratory (experimental group) intervention. The same pre and post chemistry content test was administered to control and experimental groups of pre-service teachers (herein also referred to as students), before and after learning interventions, with the aim of assessing students' achievements post- learning in the two different laboratory environments. Tests scores were analysed and the results of a paired-sample t-test showed a statistically significant difference between pre-and post-test results for all groups of students. Using independent sample t-tests, we further compared post-test scores for the control and experimental groups which revealed the mean post-test score of the experimental group $(M=79.36, S D=8.306)$, being significantly higher than that of the control group $(M=68.72, S D$ $=9.076)$ at $t(48)=4.32, p<.01$. The findings from these tests indicated that, students obtained significantly higher achievement scores postlaboratory learning interventions and that virtual laboratory interventions yielded significantly higher achievement scores than traditional laboratory interventions. Based on these findings, the researchers concluded that, laboratory learning has a positive impact on achievement in chemistry and that virtual laboratories provide a worthy complement for traditional laboratories when learning abstract and difficult chemistry concepts. Implications of these findings and some recommendations for practice and research are also discussed herein.
\end{abstract}

Keywords: Traditionallaboratories; Virtuallaboratories; Experimentation; Conceptual understandings; Content test

\section{INTRODUCTION}

In chemistry learning Laboratory-based experimentation has been proven to play a significant role in improving learners' understandings of abstract scientific concepts (Estapa, \& Nadolny, 2015). As postulated by early constructivist theorists, learning through experiences and experimentation engages learners in the meaningful 
process of knowledge construction which enhances cognition and retention significantly (Bruner, 1990). Usually, this improvement in cognition is associated with the relationship between visualisation and the formation of mental schemas within cognitive structures of the brain (Mayer, 2011). With chemistry being a core science subject, and it's content cutting across physics, biology and engineering concepts, it becomes fundamental that science students a have a good understanding of the subject knowledge. However, finding from several studies on chemistry learning indicate that, chemistry is difficult to comprehend for many students due to its abstract nature and the lack of connectedness to students' lives (Carter \& Brickhouse, 1989; Chittleborough, 2014; Kamisah \& Nur, 2013). In the South African context, the need for science to be taught as inquiry has also been widely advocated within curriculum documents and research communities, with the main aim of creating more authentic contexts for learners to visualise and grasp difficult and abstract science concepts (Department of Basic Education [DBE]: Physical sciences, 2011; Gaigher, Lederman \& Lederman, 2014; Ramnarain \& Schuster, 2014; Hsu, Lin, \& Yang, 2017). However, the scarcity of traditional laboratory learning resources for many under-resourced schools and the financial implications of trying to provide each school with its own traditional chemistry laboratory are enormous. This makes laboratory-based inquiry learning to become even more difficult to implement. It is therefore imperative that science teachers identify and implement alternative pedagogic strategies, to address the learning difficulties which are associated with the learning of abstract chemistry concepts, like the nature of chemical bonds, atomic structure, spectrophotometry and many others. In cases where schools, are equipped with all relevant resources for running a traditional chemistry laboratory, large class sizes, time constraints and laboratory safety issues constitutes some of the other limitations to effective inquiry learning within traditional laboratories (Hsu et al, 2017; Yen, Tsai, \& Wu, 2013).

With the development of novel learning technologies and the several advances registered in technology within the last three decades, the learning of science in virtual laboratory spaces has been widely advocated as an alternative pedagogic approach to address some of the limitations caused by the lack of traditional hands-on chemistry laboratory. Virtual laboratories which refer to web-based spaces characterised by the use of software in creating simulations of real scientific processes and systems are used extensively to enhance science teaching and learning (Hsu et al, 2017). These virtual laboratory spaces can be used by educators, not as replacements for traditional hands-on chemistry laboratories, but as learning tools to complement real laboratories (Hsu et al, 2017; Makranskya, Terkildsena, \& Mayer, 2017; Wu, Lee, Chang, \& Liang, 2013). With the understandings of the short comings in not always having a traditional science laboratory and the potential benefits of virtual learning in enhancing chemistry concept formation, the researchers decided to investigate the effects of virtual and traditional laboratory learning on third-year pre- service science teachers' understandings of chemistry concepts and compare the effects of traditional and virtual learning on students' achievement in content test.

\section{VIRTUAL AND TRADITIONAL LABORATORIES IN CHEMISTRY EDUCATION.}

One of the essential features of effective science teaching and learning is the incorporation of activities that target the development of science process skills through experimental and experiential learning (Abdulwahed \& Nagy, 2009). Traditional science laboratories are known to provide the relevant hub for enacting effective teaching and learning of chemistry through 
experimentation. The main aim for ensuring that students learn chemistry by experimentation is the opportunity for students to visualise chemical phenomena and make sense of learned chemical and scientific theory (Liu, Valdiviezo-Diaz, Sun \& Barba, 2015). Traditional laboratory experiments also provide students with the opportunity to experience real-life applications of concepts they have learned, experience hands-on authentic chemistry learning where products are tangible and gain science process and equipment handling skills in a real environment (Chiu, De Jaegher, \& Chao, 2015). Some of the disadvantages of traditional science labs include: limited access time; the large number of students who cannot be accommodated in a single lab at the same time; and the need for more time to prepare and carry out all investigations. With the practical shortcomings of not being able to equip every classroom with a traditional chemistry laboratory due to the expense of creating and maintaining them, alternative virtual learning tools have been considered.

The integration of learning technologies in science teaching and learning aids in augmenting the traditional pedagogical approaches that are inherent in science teaching. Virtual science laboratories are software-based tools created to mimic scientific processes as would be enabled in a traditional science laboratory (Chiu et al., 2015). Virtual learning software have been incorporated in many future fit classrooms for the simplification of science concepts ( $\mathrm{Wu}$ et al, 2013). Despite the fact that several virtual laboratories and other technology-based educational tools tend to focus on the technology rather than pedagogical effectiveness (Naidu, 2007), learners can use these virtual spaces to enhance chemistry concept formation, procedural and conceptual knowledge in chemistry learning. Some of the advantages of using virtual laboratories include the fact that they are cheaper to create and maintain than a physical laboratory, and can be accessed from anywhere, at any time. A teacher is not needed to facilitate and manage activities within a virtual space. Experiments can be repeated without waste of chemicals or other resources. Less time is required to complete the given tasks because no physical preparations are required prior to an investigation. Learners can engage in open and discovery learning without any fear of failure or making procedural errors. The interactive virtual interface is captivating and keeps learners engaged for longer (Wu et al., 2013). Some disadvantages of using virtual laboratories include mainly the hazards of prolonged exposure to computer screens. In addition, disengagement from reality due to immersion into a virtual space can be very problematic for students and the creation of tangible and physical products cannot be archived in a virtual learning laboratory space (Hsu et al., 2017; Makranskya et al., 2017).

For this study, the researchers analysed and compared pre-service teachers' use of traditional and virtual laboratories in learning four chemistry concepts: acid-base solutions, chemical reactivity, Beer-Lambert's law (spectrophotometry), the atomic structure and isotopes. The control group which constituted 25 pre-service teachers used a traditional science laboratory while, the experimental group used free online-simulated virtual laboratories (PhET) provided by the University of Colorado, in the United States of America to enhance their learning of the identified concepts. The fundamental argument with the use of virtual science laboratories is related to their relative effectiveness in enhancing conceptual understandings when compared to traditional laboratories. Also under contention is their ability to completely replace traditional laboratories, in enhancing science learning. With these various discourses, science education researchers strive to understand the affordances of virtual learning technologies for science learning and how they contribute in developing 
interest in science, attitude towards science, interest in STEM careers and achievement in science subjects.

\section{THEORETICAL FRAMEWORK}

The study is underpinned by different learning and teaching theories which combine the principles of socio-cultural theories, constructivism (learning by active participation), the cognitive theory of multi-media learning (Mayer, 2011) and the Technological Pedagogical and Content Knowledge (TPACK) framework (Koehler, Mishra \& Cain, 2013). This combination of theoretical underpinnings was considered in addressing different aspects in the creation of traditional and virtual laboratory learning interventions used in this study. Constructivist and socio-cultural theories provide a lens through which traditional hands-on laboratory experimentation is enacted in science learning. These socio-constructivist theories advocate that effective learning occurs when the learner interacts with the object of learning, and hence construct knowledge in the process (Chittleborough, 2014; De Jong, Linn, \& Zacharia, 2013). The lack of connectedness of chemistry concepts to the lives of students contributes to some of the learning difficulties in grasping concepts. Socio-cultural theorists therefore advocate that interactive learning, the environment where learning happens and the context should be taken into consideration when teaching such abstract concepts (Erdogan, 2016). In chemistry learning, this can be practicalised by providing a laboratory scenario where the students can interact with material and particle chemistry.

Constructivist theories also postulate that learners will be able to assimilate concepts better if they participate in constructing the theoretical, practical and procedural knowledge about these concepts based on the prior knowledge they possess (Bruner, 1990; Chittleborough, 2014). In his book The same and not the same, Hoffman, a Nobel Prize winning chemist, argued that chemistry students should be developed to have an understanding of "what it is that chemists do" (Hoffman, 1995:228). By this he implied that authentic chemistry learning can be achieved when student actively engage in activities that mimic the work of chemists. Chemistry laboratories and the associated chemical and physical resources provide a space where students can perform investigative tasks individually or in small groups (Crooks, Sharma \& Wilson, 2015). For example, within the school chemistry laboratory a student will be able to conduct a titration experiment to establish how many molar quantities of a base can neutralise a certain amount of acid. The advantages of engaging in this kind of experimental task are enormous in that, the student does not only learn about neutralisation reactions but also learns science process skills like equipment handling, measuring, analysing data and drawing conclusions based on empirical evidence. Research also reveals that when learners engage in experimental inquiry they are able to retain the acquired conceptual and procedural knowledge for longer (Chiu et al., 2015; Erduran \& Duschl, 2004; Lui et al., 2015).

Virtual experimentation in addition to the afore-mentioned theories is underpinned by Mayer's theory of multimedia learning and the Technological Pedagogical Content Knowledge (TPACK) framework. In virtual laboratories, students are able to use a combination of multi-media (word, pictures, simulations, motion pictures, etc) and technology to enhance visualisation, comprehension of abstract chemistry concepts and the creation of mental representations (Mayer, 2011). In training pre-service teachers, it is important they are afforded the opportunity to experience the effectiveness of these learning theories as part of their preparation for how they will engage the learners they teach once they are placed in a science classroom. As suggested by Erduran and Duschl (2004: 126), "for chemistry teaching to be 
effective, prospective teachers will need to be educated about how knowledge is structured in the discipline that they are teaching". The TPACK framework advocates that, learning can be enhanced when technology is used to complement teaching, using the right pedagogical approaches (Koehler and Mishra, 2008; Swallow \& Olofson, 2017). This implies that the right use of technology can be beneficial in enhancing science learning and vice versa.

\section{RESEARCH METHODS}

\subsection{Methodology and Design}

The study was mainly quantitative in nature characterised by numerical data (Leedy \& Ormrod, 2014). The reason for preferring this approach is related to the fact that measurable constructs such as achievement in a content test cannot be assessed using interpretivist qualitative methods (Frankel, Wallen, \& Hyun, 2015). A quasi-experimental design was also employed as a means to answer the research questions framing the inquiry. This design has its flaws in education and other social science research in that, it is difficult to isolate control groups where no interventions are provided. In educational contexts it also considered unethical to isolate a group of students from the learning process. This is because, learning is the fundamental right of all the students in each programme hence, a group of students cannot be excluded from tutorial sessions. Also, controlling contamination is not an easy task to achieve in such quasi-experiments.

\subsection{Sample}

Fifty pre-service science teachers $(n=50)$ were randomly selected form a group of 102 $(\mathrm{N}=102)$ third- year pre-service science teachers at a higher institution of learning. In this population of pre-service teachers, only 50 were majors in physical sciences (chemistry and physics) while the remaining students indicated that their interest leaned more towards life sciences (biology) teaching. The partial randomisation of the sample was effected only when allocating students to the control and the experimental group. This means that for the sample of 50 students, the chances of being in the experimental or control groups were 50-50. Online randomisation tables were used to load the names and student numbers of all participants and a program command was set to separate the sample in to two random groups, namely "control" and "experimental".

\subsection{Laboratory learning interventions}

In the first phase prior to laboratory learning interventions, all 50 participant students were given a chemistry content test (content validity established by a team of three expert science instructors) while internal consistency of the test items was established to be $\alpha=.82$ by calculating Cronbach's alpha. The test assessed students' understandings of atoms (isotopes and mass number), acid-base solutions, chemical reactions and the applications of Beer's law (see extracts of the test in appendix A). This content test was administered after students had attended the regular lectures on these topics and had a basic theoretical knowledge of the concepts. After the pre-test was marked and the scores captured on IBM SPSS 25, participant pre-service teachers were then separated into the two randomised groups of 25 preservice teachers each for participation in laboratory learning interventions.

At this stage laboratory learning interventions commenced as part of the second phase of the study. These interventions were conducted during tutorial sessions for the chemistry 
module. The control group had traditional laboratory sessions to investigate the concepts while the experimental group engaged with PhET simulation laboratories installed on their personal laptops. One of the researchers and a second tutor participated in designing and administering the learning interventions. In the first week of the intervention control group participants were taught the rules of the traditional chemistry laboratory while the experimental group was informed on how to run PhET simulations and their associated learning activities online and offline. The same learning outcomes where also given to participants in the 2 groups. After the introductory week was concluded, four weeks of the laboratory interventions on the atomic structure, acid-base solutions, chemical reactions and Beer's law were enacted respectively.

The control group was assigned to explore the chemistry concepts in a traditional chemistry laboratory, while the experimental group was assigned to investigate the same concepts using online open PhET simulation laboratories. This kind of learning intervention was guided by the principles of inquiry-based learning where the participant students were expected to ask questions, construct and test hypotheses, analyse their findings and draw logical conclusions by themselves (Ramnarain, 2010). After four weeks of completing the learning interventions a two-day gap period was given to participants before engagement with the post-test. The same content test was again administered to the participants, marked and scores recorded. Both pre- and post-test scores were captured on IBM SPSS 25 and analysed by means of descriptive and inferential statistics. Figures 1 and 2 below show sample screen shots of some of the specific activities and links for virtual laboratory experiments which the experimental group engaged in.

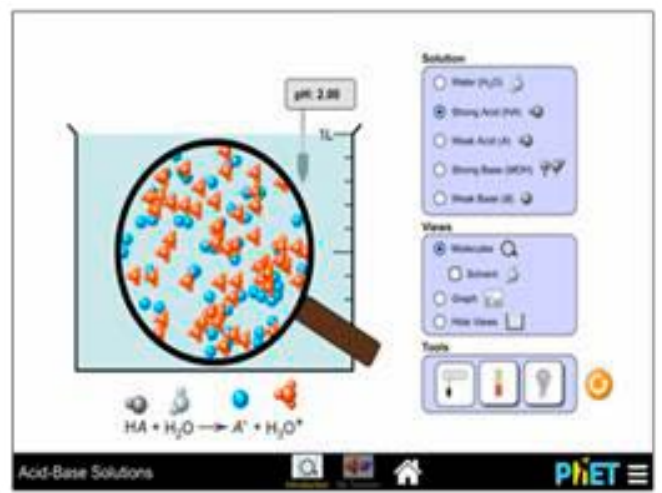

Figure 1. PhET simulation screenshot for learning acid-base solutions: (source: https://phet. colorado.edu/en/simulation/acid-base-solutions)

Figure 1 above illustrates a screen shot of an acid-base reaction activity, which preservice teachers engaged in. For the task, participants were expected to analyse the molar concentrations of acids and bases that were found in different aqueous solutions by titrating the solution against a strong/weak base or acid. By carrying out the task, the students could visualise at each stage the two-dimensional representation of the molecules of acid or bases and measure the $\mathrm{PH}$ value for the given solution. This was done both in a virtual and a traditional laboratory. 


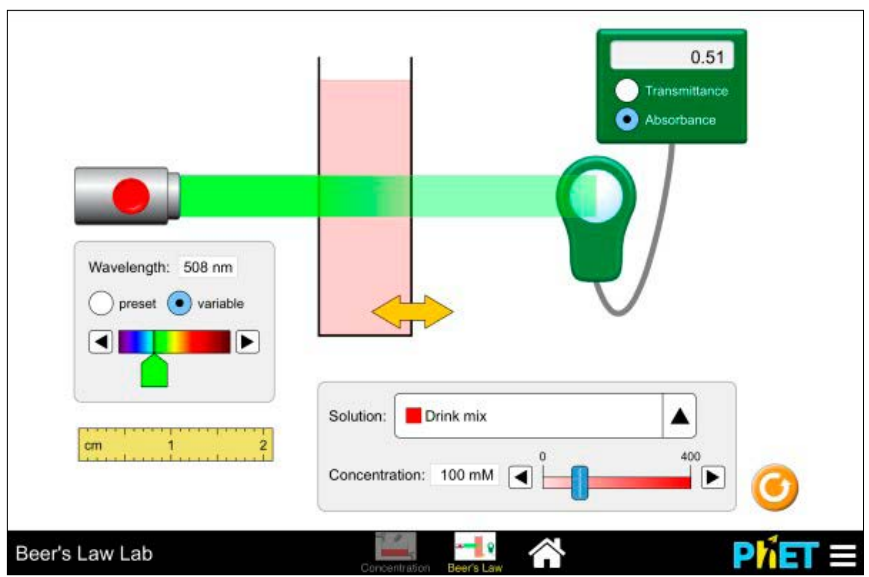

Figure 2. PhET simulation screenshot for investigating Beer's law: (source: https://phet. colorado.edu/en/simulation/beers-law-lab)

Figure 2 above shows the screen shot of a primary task where students investigated the relationship between the concentration of a solution, transmittance and absorbance as informed by Beer's law. The range of experiments covered during these intervention was also assessed in the content test as seen in appendix A below.

\subsection{Research questions}

The main research questions which guided the inquiry included:

1. What is the relationship between laboratory learning and achievement in chemistry content test?

2. Is there any significant difference in the post-intervention achievement for control and experimental groups?

\subsection{Null Hypotheses}

Ho1: There is no relationship between laboratory learning and achievement in chemistry content test

Ho2: There are no differences in the post-intervention achievement for control and experimental groups

\subsection{Data analysis and results.}

All test scores from the study were analysed using descriptive and inferential statistics with the aid of statistical software for quantitative data analysis, SPSS 25 . The results from all the statistical analysis are presented in the sections below.

\subsubsection{Normality}

In examining if there were any statistically significant differences between pre- and post-test scores for experimental and control groups, it was important to firstly establish whether the test scores were normally distributed. This rationale for establishing normality was based on the main assumptions of parametric tests; that data must be normally distributed. Based on this assumption pre and post-test scores were run through SPSS to check for a normally 
distributed data. Table 1 below shows the results of two normality tests, the KolmogorovSmirnov and the Shapiro Wilk tests.

Table 1: Test of Normality

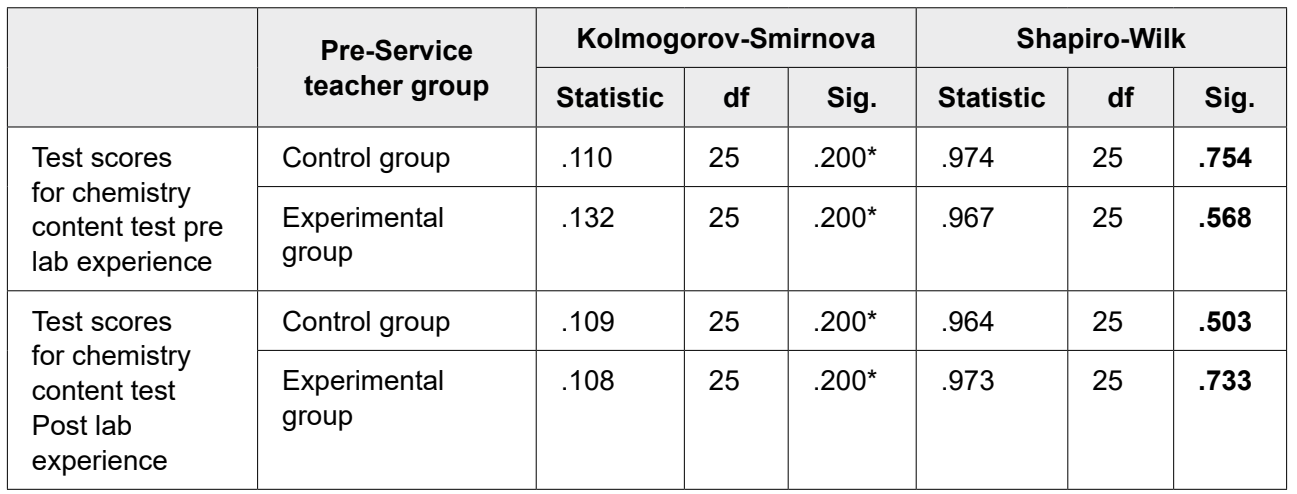

*. This is a lower bound of the true significance.

a. Lilliefors Significance Correction

As seen on Table 1 above, the results of both the Kolmogorov-Smirnov and the ShapiroWilk tests. Contrary to other statistical tests, the Shapiro-Wilk test, which is more appropriate for small sample sizes, will indicate normally distributed data when the significant $(p)$ value is $>.05$. In the case of these chemistry content tests, both pre- ( $p=.75$ and .57$)$ and post-test scores $(p=.50$ and .73$)$ were normally distributed for control and experimental groups.

\subsubsection{Pre-test and post-test descriptive and inferential statistics}

Table 2 below shows group descriptive statistics for the control and experimental test score means. For the pre-test, the groups recorded means of $M=60.20, S D=9.66$ for the control and $M=60.72, S D=9.42$ for the experimental groups, while after the intervention the posttest means for the groups were $M=68.72, S D=9.08$ and $M=79.36, S D=8.31$ for control and experimental groups respectively as shown in table 2.

Table 2: Group statistics for pre-test and post-test scores for all groups.

\begin{tabular}{|l|l|c|c|c|c|}
\hline & Pre-Service teacher group & $\mathbf{N}$ & Mean & Std. Deviation & Std. Error Mean \\
\hline $\begin{array}{l}\text { PRE-TEST } \\
\text { SCORES }\end{array}$ & Control group & 25 & 60.20 & 9.657 & 1.931 \\
\cline { 2 - 6 } & Experimental group & 25 & 60.72 & 9.423 & 1.885 \\
\hline $\begin{array}{l}\text { POST- } \\
\text { TEST } \\
\text { SCORES }\end{array}$ & Control group & 25 & 68.72 & 9.076 & 1.815 \\
\cline { 2 - 6 } & Experimental group & 25 & 79.36 & 8.306 & 1.661 \\
\hline
\end{tabular}

We further investigated whether there was a statistically significant difference in the observed means for both pre and post-test for control and experimental groups. The first independent sample t-test was carried out to establish whether there was a difference in the pre-test scores for the two groups. Findings from this test are shown in table 3 below. 
Table 3: Comparing Pre-test Means for control and experimental groups

\begin{tabular}{|l|l|l|l|l|l|l|l|}
\hline \multicolumn{2}{|c|}{} & F & Sig. & t & $\begin{array}{c}\text { Sig. } \\
\text { (2-tailed) }\end{array}$ & $\begin{array}{c}\text { Mean } \\
\text { Difference }\end{array}$ & $\begin{array}{c}\text { Std. Error } \\
\text { Difference }\end{array}$ \\
\hline $\begin{array}{l}\text { PRE- } \\
\text { TEST } \\
\text { SCORES }\end{array}$ & $\begin{array}{l}\text { Equal } \\
\text { variances } \\
\text { assumed }\end{array}$ & 1.398 & .243 & .774 & .443 & 2.560 & 3.310 \\
\cline { 2 - 7 } & $\begin{array}{l}\text { Equal } \\
\text { variances not } \\
\text { assumed }\end{array}$ & & .774 & .443 & 2.560 & 3.310 \\
\hline
\end{tabular}

In table 3, the $t$ value for the pre-test of both group was .77 at $p>.05=.44$ which indicated that there was no statistically significant difference in the pre-test marks for both control and experimental groups at a $95 \%$ confidence interval. This step was taken to ensure that pre-test means for both participant groups had no difference, which could constitute sample bias.

In answering the research question; is there any significant difference in the postintervention achievement for control and experimental groups? another independent sample t-test was conducted to establish whether there was a statistically significant difference between the post test scores for both groups. The results of the t-test revealed a statistically significant difference between the post-test scores for the control and experimental groups, $t(48)=4.32, p<.01)$. Tests showed that the mean content test score for the experimental group $(M=79.36, S D=8.306)$ was significantly higher than the mean content test score of control group $(M=68.72, S D=9.076)$, after the laboratory learning interventions as shown in table 4 below. We therefore rejected the null hypothesis "There are no differences in the postintervention achievement scores for control and experimental groups".

Table 4: T-test for group post-test scores

\begin{tabular}{|l|l|l|l|l|l|l|l|}
\hline \multicolumn{2}{|c|}{} & F & Sig. & t & $\begin{array}{c}\text { Sig. } \\
\text { (2-tailed) }\end{array}$ & $\begin{array}{c}\text { Mean } \\
\text { Difference }\end{array}$ & $\begin{array}{c}\text { Std. Error } \\
\text { Difference }\end{array}$ \\
\hline $\begin{array}{l}\text { POST- } \\
\text { TEST } \\
\text { SCORES }\end{array}$ & $\begin{array}{l}\text { Equal } \\
\text { variances } \\
\text { assumed }\end{array}$ & .209 & .649 & 4.324 & .000 & -10.640 & 2.461 \\
\cline { 2 - 7 } & $\begin{array}{l}\text { Equal } \\
\text { variances not } \\
\text { assumed }\end{array}$ & & & 4.324 & .000 & -10.640 & 2.461 \\
\hline
\end{tabular}

To answer the research question; what is the relationship between laboratory learning and achievement in chemistry content test? A paired sample t-test was used to establish whether the observed difference between the pre- and post-test means of the whole sample was significant at $95 \%$ confidence levels. Table 5 shows the result of the paired sample statistics for the entire sample $(n=50)$. With this finding we rejected the null hypothesis, "there is no relationship between laboratory learning and achievement in chemistry content test." 
Table 5: Paired Samples Statistics

\begin{tabular}{|l|l|c|c|c|c|}
\hline \multicolumn{2}{|c|}{} & Mean & N & $\begin{array}{c}\text { Std. } \\
\text { Deviation }\end{array}$ & Std. Error Mean \\
\hline Pair 1 & $\begin{array}{l}\text { Test scores for chemistry } \\
\text { content test pre lab experience }\end{array}$ & 60.46 & 50 & 9.446 & 1.336 \\
\cline { 2 - 6 } & $\begin{array}{l}\text { Test scores for chemistry } \\
\text { content test Post lab experience }\end{array}$ & 74.04 & 50 & 10.150 & 1.435 \\
\hline
\end{tabular}

The finding on Table 5, revealed that, the mean post-test score for the entire sample $(\mathrm{M}=74.04, \mathrm{SD}$

$=10.15)$ was higher than the mean pre-test scores of the sample $(M=60.46, S D=9.44)$. This led the researchers to conduct yet another Paired sample t-test in order to establish whether there was a significant difference in the observed means.

Table 6 below shows the result of the paired sample t test, indicating a statistically significant difference between pre-test and post-test scores for all the participants within the study $t(49)=-10.01, p<.01)$.

Table 6: Paired sample t-test

\begin{tabular}{|c|c|c|c|c|c|c|c|c|}
\hline & \multirow{3}{*}{ Mean } & \multicolumn{5}{|c|}{ Paired Differences } & \multirow{3}{*}{$t$} & \multirow{3}{*}{$\begin{array}{c}\text { Sig. } \\
\text { (2-tailed) }\end{array}$} \\
\hline & & \multirow[t]{2}{*}{ Std. Dev. } & \multirow{2}{*}{$\begin{array}{l}\text { Std. } \\
\text { Error } \\
\text { Mean }\end{array}$} & \multicolumn{2}{|c|}{$\begin{array}{l}95 \% \text { Confidence } \\
\text { Interval of the } \\
\text { Difference }\end{array}$} & & & \\
\hline & & & & Lower & Upper & & & \\
\hline Pair 1 & $\begin{array}{l}\text { PRE-TEST } \\
\text { SCORES- } \\
\text { POST-TEST } \\
\text { SCORES }\end{array}$ & -13.58 & 9.592 & 1.356 & -16.306 & -10.854 & -10.01 & .000 \\
\hline
\end{tabular}

\subsubsection{Practical Significance}

One of the main questions that arose when interrogating the findings of this study, is the extent to which the interventions, especially virtual laboratory learning interventions, were responsible for the variations in post-test score means. To this effect we calculated Cohen's $d$ (effect size) which refers to the standardised difference between two means and speaks to the practical significance of the findings.

Cohen's $d=$ Mean difference/pooled standard deviation

The Cohen's $d$ values between $0-0.3$ show a small effect size while those 0.3-0.6 show a moderate effect and any effect size $>0.6$ is a large effect size (Kelley \& Preacher, 2012).

For the post test scores between Experimental and control groups Cohen's $d=(79.36-68.77)$ $/((8.306+9.076) / 2)=1.22$

For the effect size of all the participants pre and post-test Cohen's $d=(74.04-60.46) /$ $((10.150+9.446) / 2)=1.39$

The Cohen's $d$ values above indicated that pre-service teachers gained 1.22 standard deviations due to the virtual learning interventions when compare to the traditional hands-on 
laboratory interventions. They also gained about 1.39 standard deviations on achievement scores in the chemistry content test after all the laboratory interventions, whether traditional or virtual. These findings are now discussed below.

\section{DISCUSSIONS AND CONCLUSIONS}

The findings of this study indicate that, all types of laboratory-learning interventions have a positive effect on achievement in chemistry content test. The specific effect size for the learning interventions showed an improvement of up to 1.39 standards deviations for all interventions, and 1.22 standard deviations virtual laboratory intervention. This implies that, while all laboratory learning interventions proved to enhance higher conceptual understandings of chemistry concepts, the use of virtual laboratories had more impact for the participant students, than traditional hands- on laboratory, as revealed by the relative effect size of the post-test scores for the control group. These findings concur with the some findings of studies within this decade, which were conducted using different virtual laboratory settings, including Abdillahi (2015), Chua and Karpudewan (2017), Estapa and Nadolny (2015) and Hsu et al. (2017). These researchers reported that virtual laboratory learning had a positive impact on learners' understandings of scientific concepts (as revealed by achievement) and stimulated interest in science subjects. The findings also confirm the theoretical underpinnings of socio-constructivism which promote learning by active participation and co-construction of knowledge (Bruner, 1990; Chittleborough, 2014). Laboratory experimentation (virtual or traditional) aided participants' leaning by enhancing visualisation of micro-chemical worlds, like atoms, bonds and molecules, which are responsible for the associated abstract nature of chemistry (Akçayır, Akçayır, Pektas \& Ocak, 2016; Hoffman, 1995). On the other hand, some researchers in science education recognise and counter the effectiveness of virtual learning in that, students do not always connect with the authenticity of virtual laboratory spaces (Hsu, et al., 2017; Wu et al., 2013). Payne (2005) also reported that 53\% of the participant students in a high school study did not endorse virtual learning at all. Other downsides of virtual learning registered included the lack of technological savviness, the loss of realism and more immersion into a virtual environment (Makranskya et al, 2017). For the current study, the authenticity of the simulators was also one of the aspects which was not very appealing to the pre-service teachers.

\subsection{Implications}

The implications, of these findings are related to alternative pedagogical approaches that should be used in enacting laboratory-based learning. Holistically, the use of experimentation in chemistry learning whether in virtual or traditional laboratory learning spaces will provide learners with a second chance to engage with learnt concepts and actively participant in verifying or generating scientific evidence. This therefore has an overall positive effect on learners' achievements in chemistry content tests In the event where traditional laboratories are scarce or not adequately resourced, virtual simulation laboratories could be employed as complementary learning tools at school and tertiary institutions to enhance students' engagement and understandings of chemistry concepts. The findings of the study also suggest that virtual laboratories, which prove to have a more positive impact on achievement scores, are worthy alternatives to consider even when traditional laboratories are available. This is because independent learning can be promoted, and trial-and-error activities can be effected in the virtual platforms before students go into a traditional laboratory session. With this notion science teachers should consider using virtual laboratories for teaching abstract concepts in all school science subjects and chemistry in particular. Even though virtual laboratories cannot replace hands-on laboratories, they are 
capable of complementing them in learning abstract chemistry concepts and promoting higher achievement scores in content tests. Curriculum experts should also consider instituting the use of virtual laboratories in science curricula globally.

\subsection{Limitations}

The sample size isolated for the study was relatively small and hence finding could not be generalised to a wider population of pre-service chemistry teachers. We therefore recommend the use of a larger sample size across different institutions of learning, in future research. A design- based research with several iterative cycles and the used of mixed research methodologies could also be employed in further investigating the affordances of laboratory learning. Only four chemistry concepts were exploited for the study and therefore we cannot assume that the experiences will be the same for all science subjects and concepts.

\section{REFERENCES}

Abdillahi $\mathrm{HH}$ 2015. The effects of simulations supported 5e teaching model on academic achievements and attitudes in physics education. Master's degree thesis. Kırıkkale: University of Kırıkkale.

Abdulwahed M \& Nagy Z K 2009. Applying Kolb's experiential learning cycle for laboratory education. Journal of Engineering Education. 93(3): 283 - 294. https://doi. org/10.1002/j.2168-9830.2009.tb01025.x

Akçayır M, Akçayır G, Pektas, MH \& Ocak MA 2016. Augmented reality in science laboratories: The effects of augmented reality on university students' laboratory skills and attitudes toward science laboratories. Computers in Human Behavior 57:334-342. http://dx.doi.org/10.1016/j. chb.2015.12.054.

Arvind VR \& Heard JW 2010. Physics by simulation: Teaching circular motion using applets. Latin American Journal of Physics Education, 4(1): 35-39.

Bruner JS 1990. Acts of meaning. Cambridge, MA: Harvard University Press.

Carter, C.S. \& Brickhouse, M.W. (1989) What Makes Chemistry Difficult? Alternate Perceptions. Journal of Chemical Education, 66(3), 223-225. https://doi.org/10.1021/ed066p223

Chua KH \& Karpudewan M 2017. The role of motivation and perceptions about science laboratory environment on lower secondary students' attitude towards science. Asia-Pacific Forum on Science Learning and Teaching, 18(2): 1-16.

Chittleborough G 2014. The Development of theoretical frameworks for understanding the learning of chemistry. In: S Devetak \& A Glažar (eds.), Learning with Understanding in the Chemistry Classroom, doi: 10.1007/978-94-007-4366-3_2, Springer Science+Business Media B.V.

Chiu JL, De Jaegher CJ \& Chao J 2015. The effects of augmented virtual science laboratories on middle school students' understanding of gas properties. Computers \& Education, 85: 59-73. https://doi.org/10.1016/j.compedu.2015.02.007

Crook SJ, Sharma, MD, \& Wilson R 2015. An evaluation of the impact of 1:1 laptops on student attainment in senior high school sciences. International Journal of Science Education, 37(2): 272-293. https://doi.org/10.1080/09500693.2014.982229 
De Jong T, Linn M C, \& Zacharia, Z C 2013. Physical and virtual laboratories in science and engineering education. Science, 340(6130): 305-308. https://doi.org/10.1126/science.1230579

Department of Basic Education 2011. Curriculum and assessment policy statement: Grades 10-12 Physical Sciences. Pretoria: Government Printer.

Erdogan N 2016. Sociocultural perspective of science in online learning environments. International Journal of Education in Mathematics, Science and Technology, 4(3): 246-257. doi:10.18404/ijemst.20679. https://doi.org/10.18404/ijemst.20679

Estapa A \& Nadolny L 2015. The Effect of an augmented reality enhanced mathematics lesson on student achievement and motivation. Journal of STEM Education, 16(3): 40-48.

Erduran S \& Duschl R A 2004. Interdisciplinary characterizations of models and the nature of chemical knowledge in the classroom. Studies in Science Education, 40(1): 105-138. https:// doi.org/10.1080/03057260408560204

Frankel JR Wallen NE \& Hyun HH 2015. How to design and evaluate research in education (9th ed.), New York: McGraw-Hill.

Gaigher E Lederman N \& Lederman J 2014. Knowledge about inquiry: A study in South African high schools. https://doi.org/10.1080/09500693.2014.954156

International Journal of Science Education, 36(18):3125-3147, doi: 10.1080/09500693.2014. 954156 Hoffmann R 1995. The same and not the same. New York: Columbia University Press.

Hsu YS Lin YH \& Yang B 2017. Impact of augmented reality lessons on students' STEM interest. Research and Practice in Technology Enhanced Learning, 12(2): 1-14. doi: 10.1186/ s41039-016-0039-z

Kamisah O \& Nur S 2013. Conceptual understanding in secondary school chemistry : A discussion of the difficulties experienced by students. American Journal of Applied Sciences, 10(5), 433-441. https://doi.org/10.3844/ajassp.2013.433.441

Kelley K \& Preacher K 2012. On effect size. Psychological Methods 17(2): 137-152. doi:10.1037/a0028086 Koehler MJ Mishra P \& Polly AB 2008. Technological pedagogical content knowledge (TPACK). Discussions with leaders in the field: SIG instructional technology. http://punya.educ.msu.edu/2008/03/11/tpack-aera-new- york/

Koehler M J, Mishra P \& Cain W 2013. What is Technological Pedagogical Content Knowledge (TPACK)? Journal of Education, 193(3), 13-19, retrieved from https://www.learnte chlib. org/p/159628/. https://doi.org/10.1177/002205741319300303

Leedy PD \& Ormrod JE 2014. Practical research: Planning and design, (10th Ed.). New York: Pearson.

LuiD Valdiviezo-DiazP Sun Y-M., \& Barba R 2015. Integration of virtual labs into science e-learning. Procedia Computer Science, 75: 95 - 102. https://doi.org/10.1016/j.procs.2015.12.224

Makranskya G Terkildsena TS \& Mayer RE 2017. Adding immersive virtual reality to a science lab simulation causes more presence but less learning. https://doi.org/10.1016/j. learninstruc.2017.12.007

Mayer RE 2011. Instruction based on visualizations. In: RE Mayer \& PA Alexander (eds.), Handbook of research on learning and instruction. New York: Routledge. 
Naidu S 2007. Instructional designs for optimal learning. In: MG Moore ed.), Handbook of distance education. London: Routledge, 247-258.

Ramnarain U 2010. A report card on learner autonomy in science investigations. African Journal of Research in Mathematics, Science and Technology Education, 14(1): 61 -72. https://doi.org/10.1080/10288457.2010.10740673

Ramnarain U \& Schuster D 2014. The pedagogical orientations of South African physical sciences teachers toward inquiry or direct Instructional approaches. Research in Science Education, 44(4): 627-650. https://doi.org/10.1007/s11165-013-9395-5

Shulman L S 1987. Knowledge and teaching: Foundations of the new reform. Harvard Educational Review, 57(1): 1-22. https://doi.org/10.17763/haer.57.1.j463w79r56455411

SwallowMJC\&Olofson MW2017. ContextualUnderstandings in the TPACKFramework. Journal of Research on Technology in Education, 49: 228-244, doi: 10.1080/15391523.2017.1347537

Tüysüz C 2010. The effect of the virtual lab. on students' achievement and attitude in chemistry. International Online Journal of Educational Sciences, 2(1): 37-53.

Wu H-K, Lee S W-Y, Chang H-Y \& Liang J-C 2013. Status, opportunities and challenges of augmented reality in education. Computers \& Education, 62: 41-49. https://doi.org/10.1016/j. compedu.2012.10.024

Yen J-C, Tsai C-H \& Wu M 2013. Augmented reality in the higher education: students' science concept learning and academic achievement in astronomy. Procedia-Social and Behavioural Sciences, 103, 165-173. https://phet.colorado.edu/en/simulation/acid-base-solutions https:// phet.colorado.edu/en/simulation/beers-law-lab. https://doi.org/10.1016/j.sbspro.2013.10.322 


\section{CHEMISTRY CONTENT TEST}

\section{Several test items adapted and reconstructed}

\section{from free online learning resources including the}

\section{Royal Society of Chemistry and PhETS).}

\section{Instructions}

Answer ALL questions on the spaces provided. For multiple choice questions, circle the right answers.

You may use non-programmable calculators.

Students are not allowed to collaborate with each other.

\section{Question 2: Chemical reactivity, balancing chemical reactions and titrations}

2.1 Which of the following equations is balanced?

$$
\begin{array}{ll}
C \mathrm{C}_{2} \mathrm{H}_{5} \mathrm{OH}+3 \mathrm{O}_{2}->2 \mathrm{CO}_{2}+3 \mathrm{H}_{2} \mathrm{O} \\
\mathrm{C}_{2} \mathrm{H}_{5} \mathrm{OH}+3 \mathrm{O}_{2}->\mathrm{CO}_{2}+3 \mathrm{H}_{2} \mathrm{O} \\
6 \mathrm{C}_{2} \mathrm{H}_{5} \mathrm{OH}+3 \mathrm{O}_{2}->2 \mathrm{CO}_{2}+2 \mathrm{H}_{2} \mathrm{O} \\
6 \mathrm{C}_{2} \mathrm{H}_{5} \mathrm{OH}+2 \mathrm{O}_{2}->2 \mathrm{CO}_{2}+3 \mathrm{H}_{2}
\end{array}
$$

2.2 In covalently bonded molecules, oxidation and reduction are determined by:

enzymes and coenzymes

products that are synthesized

uneven sharing of electrons

reactants that are broken down

gaining and losing electrons

2.3 If vou wanted to decrease the rate of reaction, what action would you need to take?

Double the reactants.

Insert a catalyst.

Increase the surface area.

Decrease the temperature. 
2.4 In general, what do Ksp values tell us about the solubility of a compound under the desianated conditions?

Smaller Ksp values mean the substance will dissolve better at lower temperatures.

Smaller Ksp values suggest low compound solubility.

Ksp values are circumstantial; we cannot know anything about a compound based on them.

6

Higher Ksp values indicate low solubility.

2.5 Consider the reaction: $\mathrm{Mg}+\mathrm{CuCl} 2=\mathrm{MgCl} 2+\mathrm{Cu}$

Which tvpe of reaction is shown above?

Combustion

Combination

Double-displacement

Single-replacement

(2 marks x $5=10$ marks)

2.6 Identify the type of reaction and balance the following reactions. You MUST show your element inventory.

2.6.1

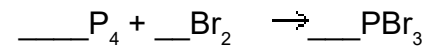

2.6.2

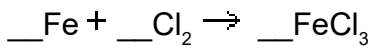

2.6.3

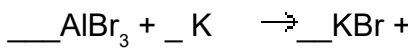
Al

2.6.4

$$
-\mathrm{H}_{2} \mathrm{O}_{2} \rightarrow-\mathrm{H} \mathrm{O}_{2}+\underset{\mathrm{O}_{2}}{\longrightarrow}
$$

2.6 .5

$$
\mathrm{PbBr}_{2}+
$$
$\mathrm{HCl} \rightarrow$ $\mathrm{HBr}+$ $\mathrm{PbCl}_{2}$

2.6 .6 $\mathrm{N}_{2}+\mathrm{H}_{2} \rightarrow \mathrm{NH}_{3}$

2.6.7

$-\mathrm{Na}+$ $\mathrm{Br}_{2} \rightarrow \mathrm{NaBr}$

2.6 .8 $\mathrm{AlCl}_{3}+$ $\mathrm{NaOH} \rightarrow$ $\mathrm{Al}(\mathrm{OH})+$ $\mathrm{NaCl}$

2.6 .9 $-\mathrm{Na}_{3} \mathrm{P}$ $\mathrm{CaF}_{2} \rightarrow$ NaF + $\mathrm{Ca}_{3} \mathrm{P}_{2}$

2.6 .10

$\mathrm{CH}_{4}+$ $\mathrm{O}_{2} \rightarrow-\mathrm{H}_{2} \mathrm{O}+$ $\mathrm{CO}_{2}$

( 3 marks $\times 10=30$ marks)

\section{Question 3: Acid base titrations}

$3.1100 \mathrm{~mL}$ of an unknown solution of $\mathrm{NaOH}$ is titrated with $3 \mathrm{M} \mathrm{HCl}$ until neutralized. The resulting solution is evaporated, and $3.0 \mathrm{~g}$ of white crystal are recovered. What was the concentration of the $\mathrm{NaOH}$ solution?
A. $1.25 \mathrm{M}$
B. $\quad 0.7 \mathrm{M}$
C. $0.3 \mathrm{M}$
D. $0.5 \mathrm{M}$ 
3.2 How many milliliters of $0.05 \mathrm{M} \mathrm{HCl}$ are required to neutralize $200 \mathrm{~mL}$ of $0.025 \mathrm{M} \mathrm{Ca}(\mathrm{OH}) 2$ ?
A. $250 \mathrm{~mL}$
B. $200 \mathrm{~mL}$
C. $500 \mathrm{~mL}$
D. $100 \mathrm{~mL}$

3.3 What volume of $0.375 \mathrm{M} \mathrm{H} 2 \mathrm{SO} 4$ is needed to fully neutralize $0.5 \mathrm{~L}$ of $0.125 \mathrm{M} \mathrm{NaOH}$ ?
A. $0.5 \mathrm{~L}$
B. $167 \mathrm{~mL}$
C. $83.3 \mathrm{~mL}$
D. $41.7 \mathrm{~mL}$

3.4 Which of the following is true regarding an acid and its $\mathrm{pKa}$ ?

I. One can increase the strength of an acid by decreasing its pKa value

II. pKa increases as the acid dissociation constant decreases

III. pKa of an acid cannot be changed by altering the concentration of the acid
A. I, II, and III
B. I and II
C. I and III
D. II and III

(3 marks $\times 4$ = 12 marks)

3.5 Consider two solutions: solution $A$ and solution $B$. Solution $A$ is a $0.1 \mathrm{M}$ hydrogen iodide solution and solution $B$ is a $0.1 \mathrm{M}$ hydrochloric acid solution. What can you conclude about these two solutions?
A. Both solutions have approximately equal amounts of hydrogen ions
B. Solution B has twice as many hydrogen ions as solution A
C. Solution $A$ has twice as many hydrogen ions as solution $B$
D. Both solutions have high pKa values.

Provide an explanation for your selected answer backing it with chemical equations (4 marks)

3.6 Consider the following reaction:

$$
\mathrm{CH}_{3} \mathrm{COOH}_{(a q)}+\mathrm{H}_{2} \mathrm{O}_{(l)} \rightleftharpoons \mathrm{CH}_{3} \mathrm{COO}_{(a q)}^{-}+\mathrm{H}_{3} \mathrm{O}_{(a q)}^{+}
$$


Which of the following changes will increase the $\mathrm{pH}$ of this solution?
A. Increasing the pKa of $\mathrm{CH} 3 \mathrm{COOH}$
B. Decreasing the volume of $\mathrm{H} 2 \mathrm{O}$
C. Adding sodium acetate
D. Increasing the acetic acid concentration
Provide and explanation for the selected choice (4 Marks)

(Total = 8 marks)

\section{Question 4: Beer's Law Spectrophotometry}

4.1. What is the absorbance of each?

4.1.1 a solution with a transmittance of 0.570

4.1.2 a solution with $43.5 \% \mathrm{~T}$

4.1.3 $0.084 \mathrm{mM} \mathrm{X(aq)}$ in a $5.00 \mathrm{~cm}$ cell if the molar absorptivity of $\mathrm{X}$ is 365 .

4.1.4 $59.5 \%$ of photons are transmitted through a cell

(3 marks $\times 4$ = 12 marks)

4.2. What is the percent transmittance of each?

4.2.1 a solution with an absorbance of 0.015 (1 mark)

4.2.2 a solution with a transmittance of 0.272 (2 Mark)

4.2.3 a $0.084 \mathrm{mM} \mathrm{X(aq)}$ in a $5.00 \mathrm{~cm}$ cell if the molar absorptivity of $\mathrm{X}$ is 365 . (2 Mark)

(Total $=5$ marks)

5. Chromatography catalogues often list the "uv cut-off" value for various solvent. This is the wavelength below which uv absorbance starts to become significant. Why are these numbers of value to anyone doing uv spectroscopy? (3 Marks)

6. A solution containing $64.1 \mathrm{ppm}$ of $Z$ had an absorbance of 0.231 in a $1.00 \mathrm{~cm}$ cell at $388 \mathrm{~nm}$.

6.1 What is the absorptivity of $Z$ ? (2.5 Marks)

6.2 If another solution of $Z$ had an absorbance of 0.767 under the same condition, what is the concentration of $Z$ ? (2.5 Marks)

7. A solution containing $40.00 \mathrm{ppm}$ of $B$ had an absorbance of 0.425 in a $1.00 \mathrm{~cm}$ cell at 690 $\mathrm{nm}$. If $5.00 \mathrm{~mL}$ of this solution was diluted with water to $100.0 \mathrm{~mL}$, what is the absorbance of the new solution at $690 \mathrm{~nm}$ ? (2 Marks)

(Total $=10$ marks)

(Grand total= 100 Marks) 